\title{
ANALYZING THE EFFICIENT ALLOCATION OF SAGO PROCESSING BUSINESS PRODUCTION FACTORS IN EAST KOLAKA DISTRICT
}

\author{
Nursalam*1 \\ *) Agribusiness Study Program, Faculty of Agriculture, Fisheries and Animal Husbandry, \\ University of Sembilanbelas November Kolaka \\ Jl. Pemuda No. 339 Kolaka 93517
}

\begin{abstract}
Sago has been widely cultivated or nourished for a long time by farmers and traditional communities in some areas such as East Kolaka District of Southeast Sulawesi Province. The purpose of this research was to know the allocation of production factors in producing sago flour and to analyze the efficiency and condition of Return to Scale of sago processing business in East Kolaka District. This research used a descriptive analysis method. The data used were primary data and secondary data. The data obtained were tested by multiple linear regression and RTS test. Based on the results of the research, it was concluded that the average revenue of semimechanical sago processing business per month was $\mathrm{Rp} 6,881,524$. Based on the analysis result, it was known that NPMx/Px of the number of sago stem was 8.78; the number of labour was 1.93, and fuel usage was 3.07 where the numbers were greater than 1 . It means that the number of processed sago stems had not been economically efficient. From the efficiency of production factor, it can be concluded that the number of processed sago stems, the number of labour, and the fuel usage was not efficient yet.
\end{abstract}

Keywords: sago processing, analysis of efficiency, revenue, production factor, return to scale

Abstrak: Sagu telah lama dibudidayakan secara luas atau dipelihara petani kecil dan masyarakat tradisional di beberapa wilayah seperti Kabupaten Kolaka Timur Propinsi Sulawesi Tenggara.Tujuan penelitian ini adalah untuk mengetahuialokasipenggunaan faktor produksi dalam memproduksiacisagu serta menganalisis efisiensi dan kondisi ReturntoScale usaha pengolahansagudi Kabupaten KolakaTimur. Penelitian ini menggunakan metode analisis deskriptif. Data yang digunakan adalah data primer dan data sekunder, data yang diperoleh diuji regresi non linear berganda dan Uji RTS. Berdasarkan hasil penelitian diporeh bahwa rata-rata penerimaan usaha pengolahan sagu semi mekanis perbulan sebesar $R p$ 6.881.524. Dari hasil analisis diketahui NPMx/Px jumlah batang sagu sebesar 8,78; jumlah tenaga kerja sebesar 1,93 dan bahan bakar sebesar 3,07 dimana angka tersebut lebih besar dari 1, artinya bahwa secara ekonomis jumlah batang sagu yang diolah belum efisiean. Sehingga dapat disimpulkan bahwa efisiensi faktor produksi menunjukan bahwa jumlah batang sagu yang diolah, penggunaan tenaga kerja dan jumlah bahan bakar yang digunakan belum efisien.

Kata kunci: pengolahan sagu, analisis efisiensi, pendapatan, faktor produksi, return to scale

\footnotetext{
${ }^{1}$ Corresponding author:

Email: noershalam@gmail.com
} 


\section{INTRODUCTION}

Sago (Metroxylon sp) is a local staple food that has been known since ancient times in some regions such as: Maluku, Papua, and Sulawesi (Ruhukail, 2012; Wiraguna et al. 2009). Naturally, sago is spread in almost every island in Indonesia, the largest area of which is in Papua, but semi-cultivation is carried out in Maluku, Sulawesi, Kalimantan and Sumatra (Syakir and Elna, 2013).

Since a long time ago, sago starch has been used as staple food in traditional foods, such as papeda, sago plate, sinole, sago porridge, sinonggi and confectionary, such as: serut, bagea and sago tumbu (Muhidin et al. 2012). Sago is one of the plantation crops producing carbohydrates between $84.7 \%$ and 3.69-5.96\% food fiber (Alfons, 2011; Syakir and Elna, 2013).

Along with the development of food processing technology, sago starch has the potential to be the main raw material for the manufacture of various food products such as noodles, vermicelli, MSG/flavorings, liquid sorbitol and fructose syrup (Purwani et al. 2006; Alfons and Rivaie, 2011). Because of the role of sago in the manufacture of non-rice food, its cultivation then should be developed continuously (Natelda, 2006).

A region with a great potential for sago cultivation development in Indonesia is East Kolaka District of Southeast Sulawesi Province. Sago processing business contributes higher income to farmers than others in East Kolaka District. The research carried out by Yamamoto (2004) found that the type of molat sago in Southeast Sulawesi has the highest yield productivity compared to other sago species in Southeast Sulawesi, which can reach more than $800 \mathrm{~kg}$ of wet sago starch per tree. Sago processing business is one type of business in the agricultural sector that has considerable potential in supporting community life in East Kolaka District. Based on the statistical data, the potential of land that can be developed as sago planting land reaches 10,567 ha of the total potential development of existing sago planting. It has grown sago for $1,710.14 \mathrm{Ha}$ with a production of 2,971.62 tons/year and its productivity is $1,737.29 \mathrm{~kg} / \mathrm{ha}$ (Department of Agriculture, Plantation, Forestry and Animal Husbandry East Kolaka, 2014).

One challenge from the technical and socio-economic aspects is how to improve the quality and quantity of production of sago processing business to achieve maximum income for sago processing. On the other hand, sago processing activities can expand business opportunities and employment opportunities from the production process to marketing of sago flour. Reviewing on it then attention needs to be directed to increased production of sago flour, farmers' income and efficiency in implementing sago processing.

Success in each processed business is expected in the implementation of sago processing business. Sago processing business is expected to contribute a high income and a lot of efficiency when compared with other sources of income. Based on that problem, the purpose of this research was to know the allocation of production factor to produce sago starch in East Kolaka District and to analyze the efficiency and condition of Return to Scale sago processing business in East Kolaka District.

\section{METHODS}

The study was conducted from January to October 2014 in East Kolaka District, one of the central forests of sago. This research used a descriptive analysis method which is meant to carry out facts, variables, and phenomena that occur at this time. The data were collected and then analyzed systemically so that they were more easily understood and concluded. The population in this study was the processor (farmers) who had sago processing business. Respondents were determined using a census method, i.e. the entire population was made as respondents (Sugiyono, 2004). Respondents in this study amounted to 61 people who were all processors of sago that had semi-mechanical processing business.

Data used in this research were primary data and secondary data. Primary data were collected from sago processors through direct interviews using questionnaires (questionnaires). Secondary data were collected from library information sources and from the Agricultural Service report, BPS, East Kolaka District Government.

Techniques and data analysis used in this study were as follows:

1. Farming gross income and total farming expenditure. Farming income gains can be used to measure the revenue earned at the farmers' family level in terms of factors of work production, management and capital 
(Soekartawi, 2003). Thus farmer's income can be formulated as follows:

$$
\pi=\mathrm{TR}-\mathrm{TC}
$$

where: $\pi$ (Farmer's income (Rp)); TR (Total Revenue (Rp)); TC (Total Cost (Rp))

2. To analyze the effect of fuel usage, a number of processed sago stems, labour, the experience of processing sago, height of sago stems, and dummy for sago type and then a multiple linear regression test (Cobb-Douglas) were performed using the following formulation:

$$
\mathrm{Y}=\mathrm{b}_{0} \mathrm{X}^{\mathrm{b} 1} \cdot \mathrm{X}_{2}^{\mathrm{b} 2} \cdot \mathrm{X}_{3}^{\mathrm{b} 3} \cdot \mathrm{X}_{4}^{\mathrm{b} 4} \ldots \ldots \mathrm{X}_{7}^{\mathrm{b} 7} \cdot \mathrm{e}^{\mathrm{U}}
$$

To facilitate the estimation of the equation, the equation was changed into multiple linear regressions with the equation model as follows:

$$
\begin{aligned}
\operatorname{Ln} Y= & \operatorname{Ln} b_{0}+b_{1} \operatorname{Ln} X_{1}+b_{2} \operatorname{Ln} X_{2}+b_{3} \operatorname{Ln} X_{3}+b_{4} \operatorname{Ln} X_{4}+ \\
& b_{5} \operatorname{Ln} X_{5}+b_{6} \operatorname{Ln} X_{6}+b_{7} n X_{7}+e^{U}
\end{aligned}
$$

Where: Y (Results Production of sago flour (kg)); $X_{1}$ (Number of Processed Sago Stem); $X_{2}$ (Number of Labor (HKSP)); $\mathrm{X}_{3}$ (Fuel Usage (liter) $\mathrm{X}_{4}$ (Business experience (year)); $\mathrm{X}_{5}$ (Water usage (m3)); $\mathrm{X}_{6}$ (Height of sago stem (m)); $X_{7}$ (Type of sago (thorny Sago and unthorny sago)); $b_{0}$ (Constant/intercept); $b_{1} \ldots b_{7}$ (Regression coefficients on each independent variable); U(Error); E (Natural Ln). Expected coefficient values were $b_{1}, b_{2}, b_{3}, b_{4}, b_{5}, b_{6}, b_{7}>0$.

Efficiency is the effort to use the smallest input to get the maximum production. Price efficiency is achieved when the ratio between the marginal productivity values (NPMx) equals the cost of input (Px) (Soekartawi, 2003). Mathematically it can be written as follows:

$$
\mathrm{P}=\frac{\mathrm{b} \cdot \overline{\mathrm{Y}} \cdot \mathrm{Py}}{\overline{\mathrm{P}} \mathrm{x}}
$$

Where: P (Production); b (the elasticity of the i-th sago production); $\bar{Y}$ (output of mean of i-th sago); Py (output of mean of $\mathrm{i}$-th sago price); $\overline{\mathrm{P}} \mathrm{x}$ (mean input price of sago i-th)

The scoring criteria were:

If $\frac{\mathrm{NPM}}{\overline{\mathrm{P} x}}>1$ then input allocation is not efficient. To achieve efficiency, input $x$ should be added. $\frac{\mathrm{NPM}}{\overline{\mathrm{P} x}}<1$, then the input allocation is not efficient yet. To achieve efficiency, input $\mathrm{x}$ should be reduced. Efficiency of price can be achieved if $\frac{\mathrm{NPM}}{\overline{\mathrm{P}} \mathrm{x}}=1$. This condition requires NPM equal to factor price of production.

Analysis of Return to Scale/RTS (Economic Scale)

RTS test was done with the following equation:

$\log Y=\log b_{0}+b_{1} \log X_{1}+b_{2} \log X_{2}+b_{3} \log X_{3}+$ $b_{4} \log X_{4}+b_{5} \log X_{5}+b_{6} \log X_{6}+b_{7} \log$ $\mathrm{X}_{7}+\mathrm{e}^{\mathrm{U}}$

with indicator used were:

H0 : $(\partial \log \mathrm{y} / \partial \log \mathrm{Xi}) \sum \mathrm{bi}=1$, means Constant Return to Scale

$\mathrm{H} 1:(\partial \log \mathrm{y} / \partial \log \mathrm{Xi}) \sum \mathrm{bi} \neq 1$, means Increasing or Decreasing Return to Scale

The next test was F test, with the hypothesis: $\mathrm{F}_{\text {count }} \leq \mathrm{F}_{\text {table }}$, $\mathrm{H} 0$ is accepted and if $\mathrm{F}_{\text {count }}>\mathrm{F}_{\text {table }}$, then $\mathrm{H} 0$ is rejected. If the test result accepts $\mathrm{H} 0$ then the economics scale is in Constant Return to Scale; on the contrary, if test result rejects $\mathrm{H} 0$ and accepts $\mathrm{H} 1$, then the economic scale is in Increasing condition or Decreasing Return to Scale.

Sago processing business is influenced by the use of production factors. In general, production will be determined by both direct and indirect factors of production. The level of production in sago processing is influenced by processor's ability to manage the production factor of sago stems, labor, fuel, water use, sago stem, sago type and processing experience. If the production factor used is efficient, then the managed business will provide maximum profit. A correct efficiency analysis will help to determine which factors of production need to be improved and which ones to be reduced. So sago processing will have the chance to gain the highest profit through economic efficiency and take the next step through the utilization of parameter value in Return to Scale. The details can be seen in Figure 1.

\section{RESULTS}

\section{Analysis of Sago Processing Business Income}

The income of sago processing business was obtained from the difference between the receipts and the expenses incurred, i.e. fixed costs and variable costs. Sago processing business revenue was calculated from 
sales of sago flour to consumers for a month. The income analysis aimed to describe a business condition in the present and the future of an activity that had been planned whether the implementation was successful or not.

\section{Fixed Cost}

Fixed cost is a cost that does not affect the size of production manufactured. Fixed cost in the analysis of sago processing business income in East Kolaka District covered the cost of depreciation of equipment. The fixed cost of sago processing business in East Kolaka District can be seen in Table 1.

Depreciation cost of equipment was calculated based on the depreciation value of the equipment used in the sago processing business. Based on Table 1, the total depreciation cost was IDR656,947 with an average life expectancy about 2.71 years.

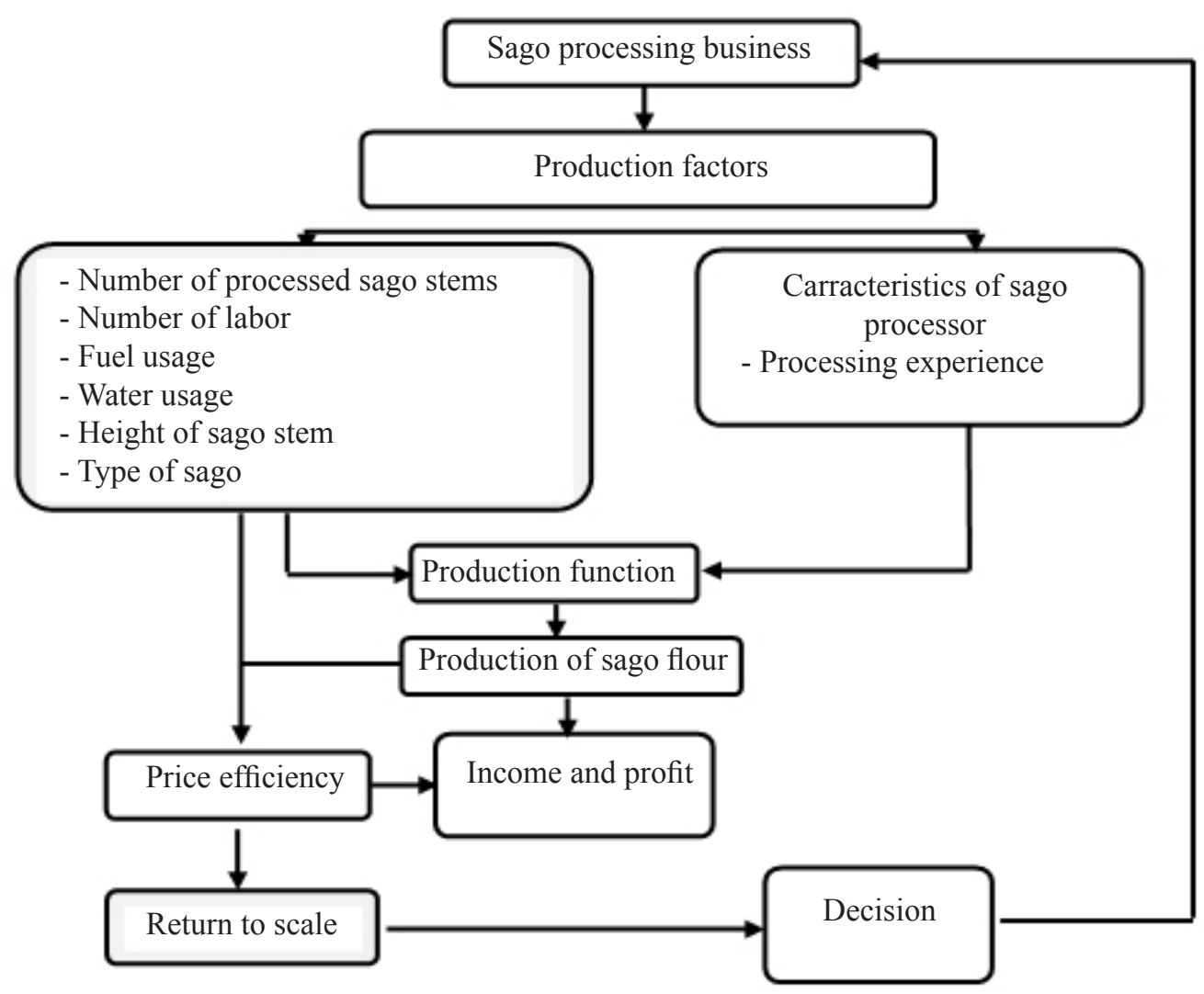

Figure 1. Research framework

Table 1. Average Fixed costs of sago processing of East Kolaka District in 2014

\begin{tabular}{|c|c|c|}
\hline Equipment & Average Economical Age (year) & Average Depreciation Value (IDR) \\
\hline Scars & 5 & 9,760 \\
\hline Lorry & 2 & 8,824 \\
\hline Crowbar & 4 & 432 \\
\hline Chopper & 3 & 5,721 \\
\hline Engine Pumps (water sucker) & 5 & 4,999 \\
\hline Shovel & 3 & 2,602 \\
\hline Axe & 4 & 3,460 \\
\hline Shelter (tarpaulins) & 0.6 & 614,190 \\
\hline Bucket & 0.6 & 3,172 \\
\hline Nets & 0.6 & 549 \\
\hline Hose & 2 & 3,238 \\
\hline Total of Depreciation & 29.8 & 656,947 \\
\hline Average & 2.71 & $59,722.45$ \\
\hline
\end{tabular}


Variable Cost

Variable Cost is the cost incurred in a production process whose magnitude varies depending on the size of the production. The variable cost of income analysis of sago processing business of East Kolaka District included fuel (gasoline, oil), sieve, sack, sago stem, rent equipment (Chainsaw), transportation lease and labor wage. Variable cost in sago processing business of East Kolaka District can be seen in Table 2. The variable cost of sago processing business was IDR8,591,516 consisting of sago stem price of IDR2,267,213.11, gasoline of IDR880,492, oil of IDR39,400, strainer of IDR49,284, sack of IDR617,550, equipment rent (Chainsaw) amounting to IDR605,328, transportation lease of IDR1,297,131 and labor wage of IDR4,164,590. From the table it can be seen that the largest cost component of sago processing business is the cost for labor. The cost for this workforce reached IDR $4,164,590$ or $48.47 \%$ of the total variable costs.
Total Cost

Total Cost is the cost of the sum of Fixed Cost (FC) and Variable Cost (VC) used in the production process. The research results were obtained as in Table 3.

\section{Revenue}

Sago processing business revenue is the product between the amount of sago production produced in kilogram $(\mathrm{Kg})$ and the selling price of sago in rupiah (IDR). Table 4 is the result of revenue from research in East Kolaka District. The total revenue was obtained from multiplying the amount of sago production and the sago price at the time of the research, namely the price of sago per kilogram of IDR2,162. Table 4 shows the income of sago farmers per month, i.e. IDR16,129,406.

Table 2. Average of mothly variable cost of Sago Processing Business in 2014

\begin{tabular}{lcccc}
\hline \multicolumn{1}{c}{ Component of Variable Cost } & Amount & Unit & Unit price (IDR/month) & Value (IDR) \\
\hline Sago stem & 17 & Trunk & 125,000 & $2,267,213.11$ \\
Gasoline & 88 & liter & 10,000 & 880,492 \\
Oil & 1.97 & liter & 20,000 & 39,344 \\
Filter & 2.87 & Pieces & 17,172 & 49,284 \\
Sack & 123.51 & Pieces & 5,000 & 617,550 \\
Rent transportation & 17 & Trunk & 75,000 & $1,297,131$ \\
Rent equipment (chaisauw) & 17 & Trunk & 35,000 & 605,328 \\
Wages of labor & 23.00 & HKO & 60,000 & $4,164,590$ \\
$\quad$ Total & & & & $8,591,516$ \\
\hline
\end{tabular}

Table 3. Average of total cost of smallholder coffee in Limbangan Subdistrict Kendal District Year 2013

\begin{tabular}{lcc}
\hline \multicolumn{1}{c}{ Description } & Price (IDR/Month) & Percentage (\%) \\
\hline Fixed Cost & 656,947 & 7.1 \\
Variable Cost & $8,591,516$ & 92.9 \\
Total Cost & $9,247,864$ & 100 \\
\hline
\end{tabular}

Table 4. Average Production and Revenue of Sago Processing Business of Kolaka District, 2013.

\begin{tabular}{lcc|}
\hline & Description & Value \\
\hline Production (Kg) & 7,460 \\
Price per unit (Kg) & 2,162 \\
Revenue (IDR) & $16,129,406$ \\
\hline
\end{tabular}


Income

The income of sago processing business is obtained from the gap between the revenue and the costs incurred, i.e fixed costs and variable costs. Revenue of sago processing business from monthly sales of sago flour to consumer. The income analysis aimed to describe a business condition in the present and the future of an activity that had been planned whether the implementation was successful or not. Table 5 is the list of income from the result of the study in East Kolaka District.

The average income of sago processing business per month amounted to IDR16,129,406 with the total cost (fixed cost + variable cost) amounting to IDR9,247,864 to obtain revenue of sago semi-mechanical processing of IDR6,881,524. The income was higher than Ruhukail's (2012) study that said the average income/month of sago processing farmers for the people of Waipaliti Village, Hitu Village was IDR3,116,818. The results of research by Damanik et al. (2013) said that the average income of traditional sago processing households was moderate (IDR3,031,260/month), and 86.48\% came from sago processing business. Ibrahim and Gunawan (2015) also proposed that the opportunity of sago income was greater than rice. The farmers' lost income due to conversion of sago land was IDR4,459,000.
Sago has great potential as the main source of starch and flour. In terms of diversity and reserves, the highest productivity of sago flour can reach 25 tons per ha, while the potential of rice, corn, wheat or potatoes to accumulate carbohydrates is only 6.0 tons, 5.5 tons, 5.0 tons, and 2.5 tons per ha, respectively (Flach, 1977).

\section{Analysis of Factors Affecting Sago Production at the Processing Level.}

Based on the F test used to test all the influence of independent variables (independent), and based on the result of calculation through SPSS version 22, the analysis result obtained Fcount $=361.290$ with the significance level of $0.000 \mathrm{~b}$. This means there was a simultaneous influence between the independent variable $(\mathrm{Xi})$ on the dependent variable $(\mathrm{Y})$. The data in Table 6 also showed that the adjusted value of $\mathrm{R}^{2}$ was 0.977 , meaning that the variation of sago flour production in the processing business could be explained by the variance of variables entered into the model of $97.7 \%$ and the rest of $2.3 \%$ was explained by the variance of other variables which were not included in the model such as the diameter of the sago stem. This indicates that the model was relatively very good because it could explain the effect of the independent variable (Xi) on production (Y). The coefficient value of the production function was the value of production elasticity where the value of the production elasticity itself showed the percentage change of production (Y) as a result of the change of the independent variable (Xi).

Table 5. Average revenue of sago processing business of East Kolaka District in 2014

\begin{tabular}{lcc} 
& Description & Value (Rp/month) \\
\hline Revenue & $16,129,406$ \\
Total Cost & $9,247,864$ \\
Income & $6,881,524$ \\
\hline
\end{tabular}

Table 6. F test of factors affecting sago production in East Kolaka District 2014

\begin{tabular}{lccccc}
\hline Model & Degree of freedom & Sum Square & Mean Square & Fcount & Sig. \\
\hline Regression & 7 & 5,016 & 0,717 & 361,290 & $0,000 \mathrm{~b}$ \\
Residual & 53 & 0,105 & 0,002 & & \\
Total & 60 & 5,122 & & & \\
$\mathrm{R}^{2}$ & 0,979 & & & & \\
$\mathrm{R}$ & $0,990 \mathrm{a}$ & & & & \\
\hline
\end{tabular}


The correlation coefficient (r) was used to determine the degree of association or the relationship between the dependent variable (Y) and the independent variables (Xi). The result of the analysis showed that the correlation coefficient (r) in the sago processing business was 0.990 with positive sign, and it could be said to be close to one. This indicates that there is a very strong relationship between the independent variable and all independent variables.

\section{Independent Variable Testing}

To determine the effect of independent variables $\mathrm{X} 1, \mathrm{X} 2, \mathrm{X} 3, \mathrm{X} 4, \mathrm{X} 5, \mathrm{X} 6$, and X7 independently of the dependent variable $\mathrm{Y}$, t-test was used. If each independent variable (X1, X2, X3, X4, X5, X6, and X7) had a positive relationship and had a significant effect, then it indicated that the higher independent variable, the higher the production of sago flour on the processing business and vice versa. If the independent variables had a positive relationship but did not have a significant effect, then the increase of independent variable would not cause an increase of sago flour production.

The summary of the results of multiple linier regression analysis of Cobb-Douglas model on sago flour processing business could be seen in Table 7. It discusses one by one the relationship and association of each independent variable to the production of sago flour. In the Cobb-Douglas production function $\mathrm{Q}=$ A.Ka . L $\beta$. There are three alternative values on the scale of the results (Return to Scale) i.e. if $a+\beta=1$, it is called Constant Return to Scale (CRS), if $\alpha+\beta<1$, it is called Decreasing Return to Scale (DRS), and if a $+\beta>1$, it is called Increasing Return to Scale (IRS).
Constant return to scale or CRS happens when each input factor changes up to $100 \%$, and the output also changes up to $100 \%$ from the initial output (Feriyanto, 2014). Based on RTS test, the calculation result obtained: $\sum$ bi $=1.157+0.165+0.191=1.53$ so $\sum$ bi $>1$, this value indicates that RTS is in the condition of Increasing Return to Scale. Test results with SPSS 22 software obtained Fcount of 361.290 with Ftable of 2.54 so Fcount $>$ Ftable meant that H0was rejected and H1was accepted, the elasticity value $>1$, it could be concluded that RTS sago processing business in 2014 was in condition of Increasing Return to Scale. Soekartawi (2003) explained that any rational processing should seek to increase income/profit, and for that reason farmers just had to increase production through the addition of input production factor (sago stem).

In general, it could be explained that of the 7 variables included in the model, there was 1 variable, the fuel usage, which rejected the hypothesis, while 6 other variables i.e. the number of sago stem, the number of labor, the experience of processing sago, water usage, sago stem height, and dummy for the type of sago accepted hypothesis at 95\% confidence level. Some variables had a positive and negative relation. This was explained by Tahir et al. (2010) that technically, the factors that affected increasing production were the level of farmer experience, the number of workforces in the family, and the dummy land tenure system. The positive and tangible relation was found in the variable of sago stem, labor, processing experience, sago stem height, while water use and sago type were also significant but had a negative relation, so the further study is needed.

Table 7. Value of multiple linear regression parameters affecting factors on sago flour production in 2014

\begin{tabular}{lccc}
\hline \multicolumn{1}{c}{ Variables } & Regression coefficient & Tcount & Sig. \\
\hline (Constant) & 6.805 & 7.945 & 0.000 \\
Number of sago stem (X1) & 1.157 & 2.772 & 0.008 \\
Number of labor (X2) & 0.165 & 2.161 & 0.035 \\
Fuel usage (X3) & 0.191 & 0.529 & 0.599 \\
Processing experience (X4) & 0.123 & 2.583 & 0.013 \\
Water usage (X5) & -0.904 & -2.338 & 0.023 \\
Sago stem height (X6) & 0.316 & 2.041 & 0.046 \\
Dummy for type of sago (X7) & -0.016 & -2.021 & 0.048 \\
\hline
\end{tabular}


Variable of sago stem with significance level 0.008 means that the amount of processed sago stem had a positive correlation and significant effect to production because every $1 \%$ increase of processed sago stem would increase production equal to $1.157 \%$. This condition was highly relevant to the general assumption that the more sago stems were processed, the greater the production that could be expected. Likewise, if the number of labor increased by $1 \%$, the production would increase by $0.165 \%$ (Ceteris paribus). In addition to the number of stems of sago and labor, the experience of processing sago and sago stems height also had a positive relationship and a significant effect on production. Based on the result of the partial analysis, it could be explained that the height of sago stem processed in sago processing business had a positive relationship and significant effect on the production because every $1 \%$ increase of the stem of processed sago would increase production equal to $0.316 \%$. This was consistent with the level of experience processing sago that had a significance level of 0.013 ; this meant that business experience in processing sago had a positive relationship and had a significant effect on production. Sago processor in research area was dominated by the experienced processor (50.10\%) and level of formal education was enough. Louw (2001) explains that in order to increase sago production, it is necessary to modify sago gauge and labor efficiency in order to increase sago surplus. Communities have been able to assemble their own machines to be used for the process of sago pith dissolving

Improvements were made to the method of harvesting and destruction of the pith through the machine tool and the type of solvent, in order to increase the sago starch yield. Meanwhile, to improve the quality, improve the color of flour and extend the shelf life of sago, the treatment on the material (pith) during extraction should be given (Hermanto et al. 2011).

Especially for the variable of water usage and type of sago processed, it had a significant effect but had negative correlation because every $1 \%$ increase of the amount of water used would decrease the production by $0.904 \%$ based on the processed sago type. While the fuel usage (X3) had a regression coefficient (b1) of 0.191 marked positive with a significance level of 0.599 , it means that the amount of fuel used in sago processing had a positive relationship but no significant effect on production. This condition was somewhat different from the general assumption that the more the amount of fuel used followed by the addition of the number of processed sago stems, the greater the expected production.

\section{Efficiency Analysis of Production Factor Usage}

The level of efficiency of production factors in sago processing can be determined by the testing of allocated efficiency. Allocated efficiency testing can be done by identifying the value of the allocated efficiency index or $\mathrm{Ki}$. The allocated efficiency index (Ki) is the ratio of the value of the marginal product (NPMx) to the production factor price (Px). Based on the result of the analysis, it is known NPMx/Px the number of sago stem equal to 8.78 (Table 8 ) while the number was greater than 1 . This means economically the amount of processed sago stems was not efficient yet. (Soekartawi, 2004) explains this condition that economically the allocation of production factor of sago stems processed at the level of $17 \mathrm{stems} /$ processing/month are relatively inefficient and to increase the profit is still possible by allocating the amount of processed sago bar at level 149 stems/processing/month ( $8.78 \times 17$ stems).

Labor production factor had an efficiency value greater than 1 (one), which means with the allocation of labor at a level equivalent to $23.00 \mathrm{HOK} /$ processing business was relatively inefficient. To increase revenue is still possible by increasing the allocation of labor to the level equivalent to $44.39 \mathrm{HOK} /$ processing business. The variable amount of fuel used (X3) had an efficiency value (NPM/HFP) greater than 1 . This condition showed that economically allocation of production factor of the amount of fuel at level 270.16 liter/processing business was relatively inefficient and to increase the profit was still possible by allocating the amount of fuel at the rate of 105 liters/processing business followed by the addition of the number of processed sago stems of 107 stems/processing. Susantun (2000) states that the definition of efficiency in production is the ratio of output and input associated with the achievement of maximum output with a number of inputs, meaning that if the ratio of output/input is large then the efficiency is said to be high. 
Table 8. Efficiency analysis of production factor with sago price variable price in 2014

\begin{tabular}{lcccccccc}
\hline Production Factor & $\mathrm{Bi}$ & $\mathrm{Y}$ & $\mathrm{Py}$ & $\mathrm{X}$ & $\mathrm{Px}$ & $\mathrm{PMx}$ & $\mathrm{NPMx}$ & NPM/Px \\
\hline Numb of sago stem (X1) & 1.157 & 7.462 & 2.167 & 17 & 125,000 & 507.85 & $1,097,971.70$ & 8.78 \\
Numb of labor (X2) & 0.165 & 7.462 & 2.167 & 23 & 60,000 & 53.53 & $115,731.86$ & 1.93 \\
Fuel usage (X3) & 0.191 & 7.462 & 2.167 & 88 & 30,000 & 16.20 & $92,230.92$ & 3.07 \\
\hline
\end{tabular}

\section{Managerial Implication}

The managerial implication of this research for sago processing in East Kolaka District is that the results of this study can be used as a consideration in the evaluation of the opportunities, processes and problems of production factors on sago processing to increase the income of sago processing business in East Kolaka District. Furthermore, identification of various obstacles or problems faced in sago processing business so far to be used as a reference on repair and improvement the quality of sago.

\section{CONCLUSIONS AND RECOMMENDATIONS}

\section{Conclusions}

Based on the results of the research conducted on the analysis of sago production function, it can be concluded that sago contributed sufficiently to sago processors' income to fulfill their daily needs, where the average monthly income is IDR6,881,542. All factors of production simultaneously affect the production of sago flour. Partially, a number of sago stems, labor, processing experience, the height of sago stems have a positive and significant effect, but the fuel has a positive and insignificant effect. On the other hand, water usage and dummy varieties of sago type influence negative and significant effect. The number of processed sago stems, use of labor and the amount of fuel used is not efficient. Return to scale condition (business scale) on sago processing business is in increasing condition of return to scale, meaning that the use of all input will proportionally increase the production of sago flour. The main source of increased production is dependent on the number of sago stems and the height of the treated sago stem.

\section{Recommendations}

Based on the results and conclusions in this study, the suggestion that needs to be submitted is to increase the sago production that can be done through the addition of production factors, such as the number of sago stems. However, because the addition of the number of processed stems is limited, it is necessary to develop/ cultivate the sago independently or with assistance from the local government.

\section{REFERENCES}

Alfons JB. 2011. Reklamasi lahan sagu mendukung usahatani berbasis sagu di Maluku. Jurnal Budidaya Pertanian 7(2): 87-93.

Alfons JB, Rivaie AA. 2011. Sagu mendukung ketahanan pangan dalam menghadapi dampak perubahan iklim. Perspektif 10(2):81-91.

[Department of Agriculture, Plantation, Forestry and Animal Husbandry East Kolaka] Dinas Pertanian, Perkebunan, Kehutanan dan Peternakan Kabupaten Kolaka Timur. 2014. Rencana Strategi Pembangunan Pertanian, Perkebunan, Kehutanan dan Peternakan Kabupaten Kolaka Timur Tahun 2010-2014. Kolaka Timur: Dinas Pertanian, Perkebunan, Kehutanan dan Peternakan Kabupaten Kolaka Timur.

Damanik IPN, Amanah S, Madanijah S, Tjitropranoto P. 2003. Strategi penguatan kapasitas pengolah sagu tradisional untuk peningkatan produktivitas usaha di Maluku.Jurnal Agro Ekonomi 31(1): 37 51. https://doi.org/10.21082/jae.v31n1.2013.3751.

Flach, M. 1977. Yield Potential of the Sago Palm and its Realization. In K.Tan (ed.) Sago-76. Papers of The First International Sago Symposium. Kucing, July 5-7. Kemajuan Kanji Sdn. Bhd. Petaling, Kuala Lumpur Malaysia: 157-177

Hermanto, Ansharullah, Nuwiyah A, Muhidin. Perbedaan Teknik Pemarutan Dan Pengaruhnya Terhadap Peningkatan Rendemen Dan Mutu Tepung Sagu. Agriplus 21(1): 30-35.

Ibrahim K, Gunawan H. 2015. Dampak kebijakan konversi lahan sagu sebagai upaya mendukung program pengembangan padi sawah di Kabupaten Halmahera Barat, Maluku Utara. Prosiding Seminar Nasional Masyarakat 
Biodiversitas Indonesia 1(5):1064-1074. https:// doi.org/10.13057/psnmbi/m010517.

Louw J. 2001. Perilaku petani sagu dalam kegiatan produksi dan konsumsi [Tesis]. Bogor: Institut Pertanian Bogor.

Muhidin, Sitti L, Makmur JA, Sumarlin. 2012. Pengaruh perbedaan karakteristik iklim terhadap produksi sagu. Jurnal Agroteknos 2(3): 190194.

Natelda RT. 2006. Analisis usaha sagu rumah tangga dan pemasarannya. Jurnal Agroferestri 1(3):5764.

Purwani EY, Setiawaty Y, Setianto H, Widaningrum. 2006. Karakteristik dan studi kasus penerimaan sagu oleh masyarakat di Sulawesi Selatan. Agritech 26(1):24-33.

Ruhukail NL. 2012. Karakteristik petani sagu dan keragaman serta manfaat ekonomi sagu bagi masyarakat Dusun Waipaliti Desa Hitu Kecamatan Leihitu Kabupaten Maluku Tengah. Jurnal Agroforestri 7(1): 65-72

Soekartawi. 2003. Teori Ekonomi Produksi, dengan pokok bahas ananalisis Fungsi Cobb-Douglas. Jakarta: RajawaliPers.

Soekartawi. 2004. Agribisnis Teori dan Aplikasinya. Divisi Buku Perguruan Tinggi. Jakarta: PT. Raja
Grafindo Persada.

Sugiyono. 2004. Statistika Untuk Penelitian. Jakarta: Penerbit Alfabeta.

Susantun I. 2000. Fungsi keuntungan Cobb-Douglas dalam pendugaan efisiensi ekonomi relatif. Jurnal Ekonomi Pembangunan 5(2): 149-161.

Syakir M, K Elna. 2013. Potensi tanaman sagu (Metroxylon sp.) sebagai bahan baku bioenergi. Perspektif 12(2): 57-64.

Tahir AG, Darwanto DH, Mulyo JH, Jamhari. 2010. Analisis efisiensi produksi sistem usahatani kedelai di Sulawesi Selatan. Jurnal Agro Ekonomi 28(2): 133-151. https://doi.org/10.21082/jae. v28n2.2010.133-151.

Wiraguna E, Bintoro HMH, Pasril W. 2009. Taksasi Produksi Tanaman Sagu (metroxylon spp.) di PT. National Timber And Forest Product Unit Hti Murni Sagu, Selat panjang, Riau. Bogor: Departemen Agronomi dan Hortikultura, Institut Pertanian Bogor.

Yamamoto Y. 2004. Starch Accumulation Process and Varietal and/or Regional Differences in Starch Productivity in Sago Palm (Meroxylon Sago Rottb.) Dalam Prosiding Seminar Nasional Sagu dan Palma Penghasil Karbohidrat. BPPT. Jakarta. 